\title{
Translation Theory between Theorization and Theoricization
}

\author{
Dr. Hasan Said Ghazala \\ Professor of Translation and Stylistics, Department of English, College of Social \\ Sciences, Umm Al-Qura University, Saudi Arabia \\ Email: hsghazala@uqu.edu.sa
}

\begin{abstract}
:
There has been an accumulation of a huge stuff of theorization about translation enveloping and cramming translation theory and threatening its existence by demeaning and probably blasting its bases, thus leading to the chaos in translation theory. Yet, a substantial part of this theorization is mere destructive theoricization that has caused considerable damage to translation theory. In translation, it aims at creating ambivalent situations and conflicting hypotheses in translation theory, tools and tactics, casting doubts on some basic topics of translation theory, including claims like untranslatability of culture, translation prescriptivism vs. descriptivism, equivalence as a chimera, breaking translation norms, regularities and boundaries, demoralising the SL text and putting it in the service of the TL culture and suspecting the definition of key terms in the field on the top of which is the term "translation. That would jeopardize the stability and credibility of translation theory as a whole, and may render it inoperative. This is indeed the most serious challenge for the substance of contemporary translation theory. The present paper is a comparative study drawn between the facts of genuine constructive theorization and damaging destructive theoricization that aims at suffocating any attempt to set out an institutionalized body of knowledge of guidelines and principles of a solid translation theory, and develop it in a systematic and on-the-ground way to tackle any new issue or problem of translation in application.
\end{abstract}


The study virtually ends up with a decisive conclusive result that, despite few shortcomings, a rigorous, practice-based translation theory does exist the world over.

Keywords: Theoricization, Translation, Translation Theory, Facts, Fallacies, Equivalence, Culture, Translation Studies.

\section{نظرية الترجمة بين التظظير والسفسطة}

الملخص

تر اكم اليوم كم هائل من التنظير حول الترجمة بات يهدد ماهيتها ووجودها من خلال التقليل من شأنها وربما

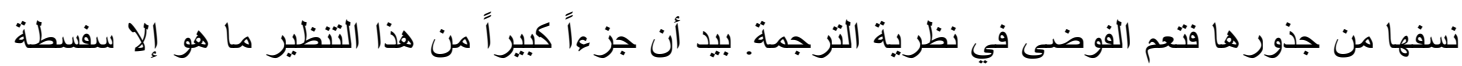
قو امها تنظير فارغ هدام غايته إلحاق ضرر كبير بنظرية الترجمة، يهدف في النهاية إلى افتعال متناقضات مفبركة وفرضيات متتاز عة في نظرية الترجمة من مثل الادعاء باستحالة ترجمة الثقافة، و اعتباطية النظرية، وأن مفهوم التكافؤ في الترجمة مجرد وهم لا أكثر ، وأن لا وجود لمعايير أو قو اعد منظمة أو حدود في نظرية

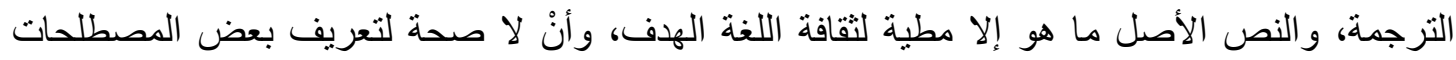
الأساسية في نظرية الترجمة من مثل مصطلح "الترجمة" ذاته الذي تطاول عليه المنظرون الفار غون وشككو الهُ فيه بغية التعريض باستقر ار نظرية النرجمة ومصداقيتها برمتها. و هنا بالفعل مكمن الخطر بل هو أخطر تحد يو اجه جوهر نظرية الترجمة المعاصرة ووجودها. يعد هذا البحث دراسة مقارنة كاثثفة لحقيقة التظير البناء و التنظير السفسطائي الفارغ الهدام الذي يهدف إلى خنق أي محاولة لوضع إطار من الأسس والمبادئ والإرشادات لبلورة أرضية صلبة من المعرفة المنظمة و العملية حول الترجمة وتطوير ها بطريقة ممنهجة وو اقعية تمكنها من التعامل مع أي مشكلة من مشاكل الترجمة في التطبيق. يتمخض عن هذه الدر اسة البحثية نتيجة كبرى مفادها أنه بر غم وجود بعض الخلل هنا وهنالك في تطبيقات نظرية الترجمة، تعتبر هذه النظرية حقيقة واقعة لا يستطيع أحد أن ينكر ها أو يزحزحها من المكانة الر اسخة التي تبو أتها في عصرنا الحاضر. 


\section{Introduction}

There has been an accumulation of a huge corpus of theorization about translation under the superordinate conception of translation theory. Yet, a substantial part of this theorization is mere theoricism / theoricization -rather than normal and logical theorization- that has caused a lot of damage to translation theory. So, a distinction between the two terms is urgently due. Theorization (hence theorist) is neutral in sense, which means by definition in general: "the suggestion of ideas about what is possibly true, and more specifically, the formulation, speculation or production of a theory (or theories)". Theoricism (hence the pejorative 'theoretician' by analogy to 'linguistician'), on the other hand, is an elaborated overdone fantasy, impractical and untrue theorization. In translation, it aims at creating confusing ambivalent situations and conflicting hypotheses in translation theory, which is detrimental to its credibility and may render it ineffective. And this is, indeed, the most serious challenge to the ontology of contemporary translation theory that is put up by pedantic theoreticians on translation. This paper is a comparative study drawn between genuine theorization and theoricization for the sake of theorization, or theoricism / theoricisation that aims at destroying any attempt to crystalize, regularize, organize, systematize, canonize or practicalize rules, guidelines and principles of a solid translation theory and develop it in a systematic empirical way and empower it to deal with any new issue, approach or problem of translation in application, not in theoricization. The study rounds up with a decisive conclusion that a flexible practice-based translation theory should be dismantled of theoricized arguments that have to be ignored and challenged drastically by means of refuting them in the daily practice of translation with confidence the world over.

\section{Repercussions of theoricization on translation theory and practice}

Theoricism / Theoricisation is an old-age practice in almost all types of theory. Being an interdisciplinary subject, translation theory has suffered most from hollow theoricisation, especially recently. It caused a great deal of damage to, and cast doubts on translation theory in general with respect to its credibility, firmness, consistency, systematicity, institutionalization and applicability. 
Statements like 'translation is impossible', 'culture is untranslatable', 'language is all in all cultural', 'translation theory is prescriptive and, hence, old fashioned', 'translators are traitors', etc. are ludicrous indeed aimed at subverting translation theory from within with the pretext of developing and updating it. Well, devastation of translation theory cannot develop anything. Take, for example, the infamous statement by famous proponents of culturalizing language, Vermeer, Snell-Hornby, Robinson and company that language is all in all cultural, and culture is untranslatable, so translation is impossible (see Snell-Hornby, 1988: 20-22 \& 4044, and Robinson,1997/2007: Ch. 10).

Well, this is a sheer fallacy that is too far from truth in practice and dismissed by the fact that translation persists and will persist so long as there is life on earth. Ironically enough, Robinson himself and other pro-cultural writers on translation are professional translators and staunch advocates of the persistence and development of translation who translate like any other professional translators. I know one proponent of this contention whose books are well-known in the field. He translates normally like us and has nothing special or different about his translations from Arabic into English and in the opposite direction. Therefore, to be more practical in our argument for the possibility of translation, and at the same time, the impracticality of the previous allegation of the impossibility of translation, we may pose the following questions, as a tester. If the answer to these questions is 'YES', the impossibility is a fallacy, if 'NO', it is a fact, then:

a. Is translation today a fact of life?

b. Is translation today a well-established discipline?

c. Is translation today a recognized profession practiced the world over?

d. Are there today professional translators everywhere?

e. Are there today translation colleges, centers, institutions, departments and courses the world over?

f. Are there today published translations of all types into a foreign language all over the world?

g. Are bookstores and libraries full of translations (Rojo, 2009: 26)? 
h. Is four-thousand-year-old practice of translation enough to justify its possibility and legitimacy (ibid.)?

i. Is the publication of translations today prosperous?

j. Are translations and interpretations today going on daily on the mass media, the Website and communications of all types at local, national and international level?

k. Are translation and interpretation today indispensable?

1. Do we understand "The House of Commons" (مجلس العوم البريطاني), “Superman" (سوبرمان), “The British Council” ”(المركز الثقافي البريطاني), “Put the

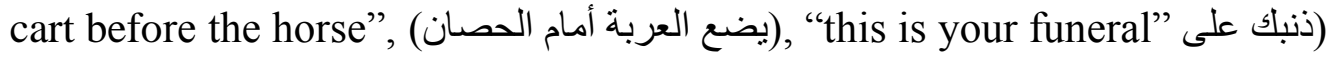
(الكيمون: رداء ياباني نسائي فضفاض؛ رداء ياباني تقليدي " the Japanese "kimono") (نسائي, etc.?

m. Do they understand الكعبة، مناسك الحج، العِرض، ألف ليلة وليلة، أيام العرب في الجاهلية، (الئل) (Ka'ba: The House of God at Makkah, Muslim Hajj rituals, jealousy for women, The famous Days of the pre-Islam Arabs, Pre-Islam Okaz poetry festival, etc.?

n. Isn't it the case that translation is not just one-to-one equivalent practice?

o. Is translation today continuing to exist?

p. Generally, at the age of high-tech and sophisticated communications of all types, is it easier to understand and accept the culture of the other?

I will leave it to the reader to draw his/her own judgement.

The counter attitude toward the translation of culture is based on the principle of language universals suggested by Chomsky and the school of generative grammar. Ironically enough, this view was originally propagated by Humboldt, Whorf and Sapir who originated the relativist theory of language. Whorf's Hypothesis has come to be known as Sapir-Whorf Hypothesis. It partly consists of (i) linguistic determinism; and (ii) linguistic relativity. According to linguistic determinism, language determines thought. However, linguistic relativity states that language encodes different distinctions (see Jakobson, 1960; Crystal, 1987; Malmkjær, 2005; and Boase-Beier, 2006 for further details). 
Sapir and Whorf maintain that each language involves two interplaying types of aspects: the particular, cultural-specific aspects as a unique way of viewing the world, and the universal aspects that languages may share with other live world languages. Some translation theorists conclude that the particular, cultural specific relative aspect of language is untranslatable (see Hyde, 1993).

Newmark draws a similar distinction between the universal (the non-cultural) and the cultural, adding a third type, i.e. the personal. He means by 'universal' common words of neutral reference that can be found in live languages all over the world like: 'sleep, study, teach, hide, write, talk, eat, drink, man, woman, people, tea, coffee, building, university, street, door, some, many, mirror, happiness, moon, mountain, money, etc. The second type, the 'cultural', is anything specific to a particular community in regard to all aspects of human life expressed by its particular language (see above). (See Ghazala (2015) for further details and hosts of examples).

It seems that these views are good for translation as a middle ground between too an overstated relativity (or particularity/culture) and an overemphasised determinism (or universality / non-culture). Both parties tend to see translation as a way of recognising the cultural boundedness of language and of being free from it. Therefore, some translation theorists see the language of translated texts as a separate language that is different from untranslated texts, what Frawley calls a 'third code' (1984). Duff calls it "The Third Language" (1981), whereas Bayely describes it as a "new" language (1992, in Boase-Beier, 2006: 24). Slobin suggests the term 'thinking for translation' for it (i.e. translation has a special language of its own) (1987). Venuti has suggested the term an 'independent form of writing' for the translated text (2000). Hamburger (1994), on the other hand, has developed a style of translation that may "... come to terms with the otherness of language" by way of enriching one's own language through the act of translation, and to move the translation toward the original source language, as Benjamin and Pannwitz suggest (in Schulte and Biguenet, 1992: 8). 
Therefore, we have to admit publicly that culture is a huge problem of translation, yet CULTURAL TERMS AND EXPRESSIONS ARE TRANSLATABLE BY MEANS OF MANY TRANSLATION PROCEDURES AND TACTICS, however difficult and inconsistent that may be. Besides that, emphasizing culture in translation excessively and more than required is neither advisable nor truthful, for culture is only one aspect of language and, hence, translation. It is far from reality to claim that language is all in all cultural, or culture is untranslatable, for if this is true, translation definitely ceases to exist altogether. But this has never been and will never happen one day. Quite the reverse, and as confirmed earlier, it is on the increase by the day. Daily practice and experience of language, translation and culture, and the many works - including my book on Translating Culture (EnglishArabic-English): A Textbook (2015)- on translation and culture, are indelible evidence for the translatability of cultural concepts and terms.

Hence, culture is only one part of language, and may be the least to occur (probably, no more than 10-15 per cent maximum in most types of texts, and cultural-specific texts are exceptions. Such simplicity of definition and practicality of placing culture in its proper status in language and translation would ease the burden of dealing with it and reflect the factual and natural stand towards culture in translation. At the same time, it counterbalances the complex, diabolic and less practical and factual maze of theorization that language is all in all cultural, and culture is language.

\section{Negotiating Cross-cultural Differences in Translation:}

Many translation theorists and professional translators give the impression that the problem of translating culture is formidable, the most difficult and sometimes insuperable in the practice of translation. Well, first of all, nothing in translation problems can be described as insuperable to sort out. $\underline{\text { Second, the cultural }}$ differences between English and Arabic are overstated as hosts of examples of identical culture exist in them. Third, cultural differences that are specific to each language and have no one-to-one equivalent are approached differently and flexibly in translation. Fourth, the biggest problems of translating culture lie especially in one group of cultural terms and expressions, 
That is, the sensitive ones that may be insulting, aggressive, conflicting and repulsive and, hence, might result in a serious clash between the two cultures and the SL and TL readerships concerned. The translator's dilemma is how to approach these clashing cultural expressions in translation, especially from English into Arabic.

As to the first, it is an ipso facto now that nothing in language is untranslatable, and that "everything without exception is translatable", as Newmark says (1988: 6, 7273). This basic principle in translation draws heavily on the understanding of translation as not merely a one-to-one equivalent practice, but as a translation of the SL meaning into the TL either identically, closely, approximately or by transference, whichever is applicable. That is, 'The Hand of God' has an identical Arabic expression as يد اله , قدر اله is translated approximately into the 'Two Holy Mosques', but القرآن is transferred into English as 'The Koran', without changing the Arabic pronunciation, and without giving its meaning. All these and other types of rendering cultural meanings into another language disregard the number of words of the SLT, which are as few as possible and as many as required.

The second issue about overstating the cross-cultural differences is best confirmed by the enormous number of similar cultural expressions of different types between English and Arabic Languages, two remote cultures, as illustrated by the following miscellaneous examples:

\section{Conclusions: (1-4)}

\section{Identical equivalence}

- Smoking habit(عادة النتخين)

- Social habit(عادة اجنماعية)

- Reading habit(عادة القراءة / المطالعة)

- Acquire a habit(يكتسب عادة)

- Give up a habit(يقلع عن عادة)

- Change a habit(يغير عادة) 
- Get rid of a habit(يتخلص من عادة)

- Eating habits(عادات الأكل)

- Drinking habits(عادات الثرب)

- Blind confidence (نقة عمياء)

- Toss down the bitterness of defeat (يتجر ع مرارة الهزيمة)

- Wonderments and bewilderments (عجائب و غر ائب)

- Winking and blinking (الغمز و اللمز)

- By sheer coincidence (بمحض المصادفة)

- wash one's hand of something (يغسل يديه من أمر ما)

- In at one ear and out at the other (يدخل من أذن ويخرج من الأخرى)

- Raging storm (عاصفة هوجاء)

etc. (See Ghazala, 2007 for over one hundred thousands of examples).

\section{Close equivalence (one-part correspondence)}

- Prime of life(مقتبل العمر/ربيع العمر)

- Go to earth(تبلعه الأرض)

- $\quad$ Live and learn (تعيش وتنشوف)

- Take the lead (يأخذ زمام المبادرة؛ يصبح في المقدمة)

- Brain drain (هجرة الأدمغة)

- Poet laureate (أمير الثعر اء)

- $\quad$ sound sleep (سبات/نوم عميق)

Etc.

\section{PROVERBIAL SIMILES ('as...as' constructions)}

\section{Identical equivalence}

- As strong as a horse(أقوى من الحصان؛ مثل الحصان)

- As slow as a tortoise (أبطأ من سلحفاة)

- As swift as an arrow(أسرع من السهم)

- As cunning as a fox (أمكر من ثعلب؛ ماكر كالثعلب)

- As innocent as a child (بريء كالأطفال؛ بر اءة الأطفال)

- etc. 


\section{Close equivalence}

- as merry as a lark (أسعد من فتبرَّة) (أسعد مصنور)

- as secure as the grave (آمن من الأرض) (آمن من القبر (not)

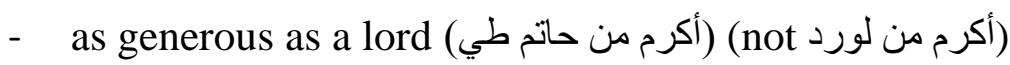

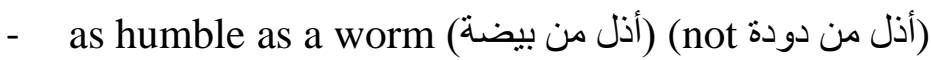

- as remote as a dream (أبعد من الثريا) (أبعد من حلم (not)

etc. See Oxford, 2003; Benson et al, 1986 and Ghazala, 2007 for a wide range of examples).

\section{METAPHORS AND IDIOMS}

\section{Identical equivalence}

- I am thirsty to see her (أنا متعطش لرؤينها)

- See no further than one's nose (لا يرى أبعد من أنفه)

- Fish in troubled waters (يصطاد في الماء العكر)

- Time is gold (الوقت من ذهب)

- Our manager is a fox (مديرنا ثعلب) etc.

\section{Close equivalence}

- Slam the door on... (يوصد الأبواب في وجه كذا)(not)(يوصد الباب على)

- Save one's face (يحفظ ماء وجهه) (not (يحفظ وجهه)

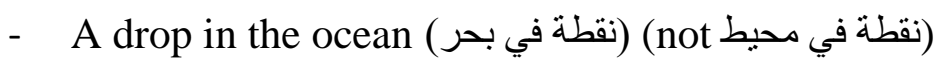

- Hands of the clock (عقارب الساعة) (أيدي الساعة (20t)

- Foot of the mountain (سفح الجبل) (not (قدم الجبل)

\section{PROVERBS}

\section{Identical equivalence}

- All that glitters isn't gold (ما كل ما يلمع ذهباً)

- Love is blind (الحب أعمى)

- Need is the mother of invention (الحاجة أم الاختراع)

- As you sow, so will you reap (كما تزرع تحصد) 
- Every why has wherefore (لكل سؤال جواب)

\section{Close equivalence}

- Blood is thicker than water(الدم لا يصير ماء)(rather than Bمك من الماء)

- Dig one's grave with one's teeth (يحفر قبره بيده) (rather than يحفر قبره بأسنانه)

- Familiarity breeds contempt (الألفة تُذهب المهابة) (rather than الألفة نولد الاحتقار)

- Forbidden fruit is sweet (كل ممنوع مرغوب) (rather than (ملثرة الممنو عة حلوة )

- Patient men win the day (من صبر ظفر معرع) (الصبورون يكسبون يوماً ما)

\section{CALQUES (of all types of expressions):}

Cultural calques are so many in Arabic nowadays, and the door is wide open for them unconditionally. It is hoped that this door be left open, but not so widely (see the next point). Here are examples:

\section{Identical equivalence}

a. Computer virus (فيروس الكمبيوتر)

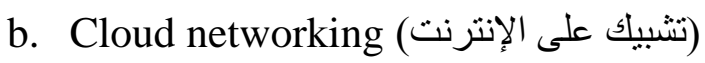

c. Data bank (بنك معلومات)

d. No smoke without fire (لا دخان من دون نار)

e. Sow division (يزرع الثنقاق)

f. Brainwashing (غسيل دماغ (ئز)

g. Lukewarm reception (استقبال فاتر)

h. The ball is in their court (الكرة في ملعبهم)

i. The Englishman's house is his castle (بيت الإنجليزي قلعتهة)

j. All the roads lead to Rome (كل الطرق تؤدي إلى روما)

k. The means justifies the end (الغاية تبرر الوسيلة)

1. Parliament (البرلمان)

m. Ballot box (صندوق الاقتراع)

n. Constituencies (دو ائر انتخابية)

o. Hamburger (الهمبورجر)

p. Fast food (وجبات سريعة)

q. Facebook, Twitter, YouTube, etc. (الفيسبوك، التويتر، اليو تيوب) 
r. The Pentagon (البنتاجون)

S. Corona virus (فيروس كورونا)

t. Bids' flu (إنفلونز ا الطيور)

u. Swine flu (إنفلونز ا الخنازير)

etc. (The list is too long indeed.)

The third point related to the specific cultural differences that have no one-to-one equivalent are approached differently and flexibly in translation. A great number of translation procedures, strategies and / or tactics are employed to solve the problems of translating culturally different terms. Some examples can be cited in here (full details are forthcoming in the book):

- Transference + paraphrase /translation couplet (e.g. الكعبة : Ka’ba (The Holy House of God at Makkah))

- Through translation (e.g. هيئة الأمر بالمعروف و النهي عن المنكر (The Bureau of enjoining good and forbidding evil)

- Paraphrase: (e.g. المشاعر (Hajj holy sites at Makkah))

- Classifier (e.g. Old Trafford (ملعب أولد ترفورد / ملعب مانشسنر يونايتد لكرة القدم))

- Non-culturalization/neutralization (The Dream Stadium ملعب مانشستر يونايتد)) (الثهير)

- Naturalization (e.g. The Olympic Games/the Olympics (الألعاب الأولمبية)) etc.

The Fourth point regarding the tricky problems of translating sensitive cultural terms may result in a serious clash between the two cultures and the SL and TL readerships concerned. The translator's dilemma is how to approach these clashing cultural expressions in translation, especially from English into Arabic. For the time being, the procedure of responding by a counter comment can be suggested here, to be followed up by other strategies below in this Chapter, and in the next parts of the book:

- The Koran is Mohammad's Book (بل هو كتاب الله) (القران كتاب محمد)

- Assad of Syria fights terrorism (بقاتل الأسد في سوريا الإرهاب) (بل الإرهاب بعينه) 
- Palestine is the Promised Land for the Jews (فلسطين هي أرض اليعاد لليهود) (فل ) هي وطن الفلسطينيين)

- Islam is the religion of the Arabs of the Peninsula only. الإسلام دين عرب شبها الجزيرة العربية فقط) (بل هو دين العالمين)

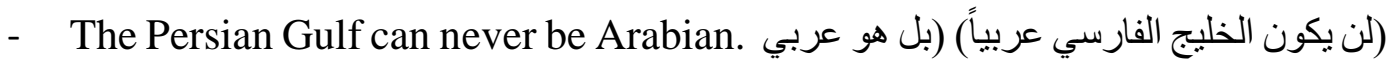
ولن يكون فارسياً أبداً)

etc.

\section{Fallacies of theoricization vis-à-vis facts of theory of translation}

Like any other theory, and to be called a theory, translation theory is expected to be consistent, systematic, logical, rigorous, transparent, applicable and, above all, practice-based and practice-oriented. Any theory that fails to meet these prerequisites is incompetent, with the realization of the fact that no theory of translation or other is infallible, though. Infallibility of translation theory does not exist and nobody has a claim for it, yet this does not nullify it, or, else, no theory of anything of any type in any field including science exists. Nothing human is infallible.

That said, finding unsubstantial faults or shortcomings with a theory does not render it invalid. And that is exactly the case with contemporary translation theory. It occasionally lacks consistency, comprehensiveness, rigor and/or applicability, yet this is not unexpected with a theory of an interdisciplinary subject like translation. But that is not serious enough to endanger its validity and stability. The basics are there: translation principles and knowledge, translation methods, translation tactics / strategies / procedures, translation tools, text types, three-staged translating process (prior to translating, at translating and after translating), translation criticism / evaluation, translation revising and revisers, types of equivalence, problems of translation of all types (lexical, grammatical, stylistic, pragmatic, etc.), solutions to problems of translation, and so on. All are based on, derived from and directed to practice and application. Within this framework, there are variations and differences that are normal, but not insuperable. 
In latest developments of translation theory, a tide of fallacious anti-theory trends of theoricization has overwhelmed it in an attempt to spoil the apple cart, as it were, casting doubts on almost everything at the heart of translation discipline and theory, including the word "translation' itself. They introduce theses and antitheses that resist any kind of synthesis on the ground in translation practice. These aim at disrupting, or perhaps annihilating the whole body and framework of translation theory, whether their antagonistic protagonists mean it or not. That is, they say something and refute it later on; defend it and then attack it, call for it and at the same discard it, and so on and so forth. For example, they attack what they call translation theory traditional and prescriptive, and call for a descriptive theory of translation. A short time later, they admit that desriptivism is sometimes inevitable in the theory, and dictate their descriptive approach to translation theory in a prescriptive style, using the same prescriptive word "should" recurrently in their argument, which is exactly the very criticism of the prescriptive style of "using "should" they label against prescriptive translation theory referring in specific to Newmark's use of the word "should", as indicated below. Another paradoxical statement is their objection to norms of translation theory, and at the same time acknowledging the need for norms in translation theory. Here is a brief table of juxtaposition illustrating the views of theoricists that run counter to established issues of translation theory:

\begin{tabular}{|c|c|}
\hline Translation Theoricization & Translation theory / theorization \\
\hline $\begin{array}{l}\text { (1) Language is all in all cultural. } \\
\text { (2) Culture is untranslatable, and } \\
\text { since language is cultural, and } \\
\text { culture is untranslatable, } \\
\text { translation is impossible. }\end{array}$ & $\begin{array}{l}\text { (1) Language is partly cultural, partly } \\
\text { universal. } \\
\text { (2) Culture is no doubt translatable, so } \\
\text { translation is possible. The } \\
\text { evidence for that is that translation } \\
\text { has been going on in the world for } \\
\text { over four thousand years and still. } \\
\text { (3) All words without exception are } \\
\text { surely translatable for translation is }\end{array}$ \\
\hline
\end{tabular}


(4) Translating the untranslatable.

(5) Legal translators translate one legal system into another legal system.

(6) Translators are traitors.

(7) Communicative/dynamic translation aims at producing an effect on the TL reader that is similar to that produced on the SL readers. not a one-to-one equivalent

practice. So nothing is

untranslatable in language;

everything is translatable via

translation procedures, tactics or strategies.

(4) A paradoxical phrase: the untranslatable is translatable for if we translate it, it is then translatable.

(5) Legal translators translate the language of law into a legal target language, not a legal system into another legal system.

(6) Bad translators can be traitors, but professional translators are dignified mediators and communicators among languages.

(7) Communicative/dynamic translation aims at producing not an artificial or replica effect, but a practical effect on the TL readers in terms of their language and culture irrespective of any comparison with the SL readers. This effect is not dictated by the SL author or readership, but by the SL text whose language implies and imposes producing an effect on the TL reader. 
(8) Poetry is translated by a poet only.

(9) Equivalence is a chimera in translation.

(10) There are no norms of translation.

(11) Translation theory is prescriptive but it should be it is also descriptive.

(12) Prescriptivism vs. descriptivism.
(8) Poetry is translated by a poet as well as any able professional translator who is well-versed in the prosodic, aesthetic, stylistic, rhetorical and other features of the language of poetry in both languages involved.

(9) Equivalence is an intrinsic fact inculcated in any translator's brain by nature anywhere at tackling any type of text with variations, though. The first thing that jumps to the translator's mind is to look for direct equivalence. However, when a direct, one-to-oneequivalent is unavailable, he/she resorts to translation tools and tactics to resolve the problem and render an approximate sense to the TL.

(10) There are all kinds of norms of translation.

(11) Translation theory is prescriptive but flexible, and cannot be descriptive only.

(12) Cynical paradox of the theoricist approach to current translation theory. 
Following are five major theoricized contentions that clarify best my point of argument against theoricism and theoricists, and how they contradict themselves and cause damage to translation theory:

\section{Prescriptive theory vs. descriptive theoricization}

Toury (1995a \& 1995b) upset linguistics-based studies of translation by opposing prescriptivism (Pym, 2016), refusing prescriptive statements indicated by the recurrent use of "should". Peter Newmark's use of statements including "should" repeatedly and in the same way were criticized sharply by Toury. He says: Statements like "In principle, in authoritative and expressive texts ... $\underline{\text { should be }}$ translated literally" (Newmark 1988: 112), or "translations should aim to have the same effect on their target readers as the source texts had on the source readers," or "translators should translate transgressively, not fluently").

\section{Comments on prescriptivism vs. descriptivism}

(1) The same style of prescriptivism is adopted by Toury himself when talking about his view of a descriptive Translation Studies. He insists that translations should be studied in terms of their target contexts rather than in relation to their sources (see Toury 1995b: 136). This led to an extreme position: in Toury's words, "translations should be regarded as facts of target cultures" (1995b: 139; cf. 1995a: 29). This proposition, he continues, should be understood as part of a specific research methodology (three consecutive uses of prescriptive style of "should" in the same way done by Newmark who was criticised by Toury, as just mentioned. A further example of prescriptive descriptivism is the following obligational "must" statements: " In the first place, language must be viewed not as a cognitive construct, but as a shared set of habits using the voice to communicate. In the second place, language must also be viewed as potentially and actually idiosyncratic and sociosyncratic ..."

(2) Yet again, Toury himself, who describes Translation Studies as descriptive, admits that it is prescriptive for the descriptive paradigm has not been able to impose its disciplinary map on all other paradigms, and that the proponents of description were not entirely closed to the rest of the world. (Toury and 
Lambert 1989: 1). Further, his account of descriptive paradigm for translation studies (i.e. translation theory) has turned to be by and large prescriptive. The following are points that would generally be considered positive aspects of the descriptive paradigm, challenged by prescriptive aspects of the same paradigm:

$>$ The historical variety and vitality of translation has been revealed. The paradigm has played a central role in the legitimization of Translation Studies as an academic discipline.

D It has created knowledge that is potentially useful for all aspects of Translation Studies, including the prescriptive approaches it originally opposed.

It breaks with many of the prescriptive opinions of the equivalence paradigm, albeit at the expense of creating its own illusions of objectivity.

The counterweight to these points must be a series of arguments about the apparent failings of the paradigm (Pym, 2016):

- The descriptivist enterprise is ultimately positivist [i.e. prescriptive], without awareness of its own historical position and role.

- The definition of "assumed translation" [suggested by Toury in his paradigm] is circular, and must at some stage rely on the theorist's own criteria [i.e. prescriptivism].

- Descriptions do not help us in the training situation, where we ultimately need prescriptions.

(3) Prescriptivism usually has a pejorative sense (which I object to generalizing it) associated with translation theory to pave the way for newly introduced plausible descriptive approaches to translation (which are not always applauded). The result has been mainly mere theorization that is close to futile theoricisation, which is in other words theorization for the sake of theorization aimed at understating translation theory. 
That said, not everything prescriptive is outdated unless inapplicable. And translation theory is still quite applicable on a large scale worldwide.

(4) Moreover, replacing a prescriptive approach with a descriptive approach involves the possibility of applying the latter to different texts and in different contexts and situations in the field of translation, which is not the case as we have just indicated. That is, Toury's paradigm is circular and requires criteria (i.e. prescriptivism.).

(5) On the other hand, if the descriptive approach is adopted in translation theory (or the modernistic term, "Translation Studies", which downgrades translation theory to "studies" only that fall short of theory, and perhaps denies its existence in the first place) in the sense of describing how translators translate, how can translation theory (or "studies"!) develop and improve? Description of the status quo of current translations will be a standstill situation that may not achieve progress as hoped for. New developments of translation theory and approaches are expected to spring from the infinite source of practice in different texts, contexts, situations, cultures, communities and conditions of all types and aspects. In fact, descriptive theoricists / theoreticians of translation always play on the tune of the negative connotations of terms like prescriptivism, tradition, conventions, norms and so on.

(6) More to that, as Lefevere (1992) notes, the descriptive approach was not very useful when it came to decide what good translation is and what is bad. Only a prescriptive approach is able to decide that according to certain criteria derived from translation theory and practice.

(7) Above all, and as Pym (2016) rightly inquires, if the aim of the descriptivist approach of translation studies were merely to describe, there would be little need for any grand theory. And yet what we find in this descriptive paradigm is an account of a host of theoretical concepts: systems, shifts, norms, universals and laws, to name the most prominent, 
plus a long ongoing debate about how to define the basic term "translation" itself!

(8) Despite the emphasis on description, this remains very much a paradigm for theoretical activity. In other words, description of translation corpus is a mere description and cannot be a theory for the simple reason that if we describe a text, or anything else, we are not forming a theory, but giving an account of specific features of certain types of the text or the thing described.

\section{Discarding translation norms}

Descriptivist theoreticians led by Toury call for renouncing norms. They shun any kinds of rules, systems, regularities, principles and guidelines in translation theory. They are anti-canonists, as it were, refusing to recognize any framework of reference of translation theory with the pretext that anything related to norms of translation would be prescriptive, and prescriptivism is discarded by descriptivists. Translation norms to Toury and company are there just to be broken, and not to be followed.

\section{Comments on discarding translation norms}

(1) Further, a descriptive approach is useless and inapplicable in translation training for what to describe to trainee translators and translation students who start from the scratch and have no background knowledge about translation? So prescriptivism is inevitable again. Toury's proposal (1992) to train students how to break norms in a training situation - as he himself has done within Translation Studies - is impractical and useless for students who have yet to be introduced to the subject of translation which they ignore almost entirely. So how can they be exposed to different texts? In what way are they going to be trained to break the norms of translating, and what for? Above all, in the first place how will they break something they don't know about? They have to be introduced to the norms of translation, first, and then learn about breaking them! Again prescriptivism is hovering there in the descriptivists' approach unknowingly. 
(2) Hence, to descriptivists, translation norms are there to be broken, not to be followed as a guide to translators. They claim to have done that by way of new developments to translation theory (or studies?). In the descriptive translation theory, and as pointed earlier, students of translation should be taught how to break prescriptive translation norms and translate according to criteria outside translation like sociology and sociolinguistics. According to the sociolinguistic approach to translation adopted recently by figures like Toury, Brisset, Sergey Tyulenev (2014) and others, the social context defines what is and is not translatable and what is or is not acceptable through selection, filtering and even censorship. Indeed, some descriptivist translation theorists have recently called for a "sociological turn" and moved toward the incorporation of sociological models. According to this sociological perspective, a translator is inevitably a social being and the product of his or her society: our own sociocultural background is present in everything we translate. This reminds me of the American stylistician, Stanley Fish's suggestion of the "interpretative community' of the society to be the frame of reference of the text's stylistic interpretation (1980). Again, this is another backtrack to norms of translation, social norms, that is. Clearly, descriptivist theoreticians are disparately after norms of some kind even though from outside the discipline of translation, which can be justifiable. But this is not the point; the point is they realize the essential importance of having norms in translation to be the frame of reference, the basis, or the canon for people in the field to work forward to it and draw comparisons, contrasts and juxtapositions of different translation elements, activities, tools and tactics.

(3) Translation descriptivists who call for disposing of translation norms admit that the aim of Translation Studies is to discover laws. One may ask: "aren't laws norms? Toury himself again contradicts himself by admitting that descriptive Translation Studies aims at the formulation of abstract laws based on numerous observed facts. Aren't abstract laws norms, again?

(4) Further, Toury contradicts himself one more time by maintaining that "... the concept of norms has helped bridge some of the gaps between descriptivism 
and prescriptivism. In other words, he admits the existence, or rather, coexistence of prescriptivism and descriptivism in translation theory." (in Pym, 2016).

(5) Chesterman (1999) argues that empirical research should reinforce training, to predict the success or failure of certain strategies. Norms and regularities of some kind are sought for almost everywhere by almost everybody. This is further indelible evidence added to the body of evidence for the need for translation norms. Theorists and theoreticians may have differences on the types of norms, but they agree on the need for them.

(6) In her book Text analysis in Translation (1991), Christiane Nord suggest a didactic approach to teaching translation in the classroom that aims to provide "criteria for the classification to all text types for translation classes, and some guidelines for assessing the quality of the translation". In his review of the book in (1993), Pym concludes that the book should be of extreme interest to anyone seeking a sold basis for the training of translators. The book also includes a series of theoretical principles in its first Part. Pym rightly states that "the approach is nothing if not systematic". In other words, both Nord and Pym call for norms in the teaching of translation implied in the underlined words (i.e. criteria, guidelines, basis, principles and systematic approach). That is why we need norms in translation, be they prescriptive or not.

(7) After all, what is wrong with having well-established norms of translation? Don't we have norms of language? Norms and conventions of reading literature? Norms of critical discourse? Norms of living? Norms of research? Norms of almost everything? Take, for example, language. How can we speak or write any language in the world without norms and rules. If I, the writer of an academic paper use broken English, for example, is it normal? Of course not! Language has rules and norms to organize and systematize itself in use so that its speakers can learn it through these rules and norms. Otherwise how can we learn any language, or anything without rules and norms. All attempts and bids against language norms have failed including that of the American poet, e.e. cummings, who writes his name in small letters for he does not 
recognize capitalization rules of English. He also wrote his poems in broken English (see his famous poem entitled, "he danced his did", which is completely in broken English, or, rather un-English), but nobody followed him suit. By the same token, if translation without norms persists, chaos will prevail. Just imagine that there are no translation methods, text types, guidelines for the process of translating, no account of translation tactics, tools, procedures or strategies and how and when to employ them in translation, no ethics of translation, no approaches to translating the different types of texts and languages, no account of translation problems and their solutions of different types in different texts and contexts for different target language readership, no distinction or recognition of variations and differences between SL and TL readers, no knowledge of the dynamics and pressures of the SL and TL, etc. Imagine that people, any people, translate the way they like, whatever they wish, without knowing anything about rules and guidelines of how, what, why, when, what for, to what purpose, to who and in what way to translate! Finally, imagine that there is no translation norms or translation theory at all! No one I guess can imagine that.

(8) To me, norms to language and translation are like security to the communities; they are urgently and inevitably required to systematize them. That said, it should not be concluded from the inevitability of norms that they are permanently fixed and do not change. Quite the reverse, translation norms and rules are flexible guidelines and recommendations for translators to help them regarding the types of texts, methods, procedures, problems, solutions, terminology, different contexts, types of readership, SLT and TL gravitations toward and against, types of pressures on the translator, and so on and so forth. All these guidelines and issues represent a huge body of knowledge, a translation theory corpus of frame of reference that is flexible enough to allow for any updating of changes, modifications, new explorations, issues, approaches and conceptions that can open up new revenues and pathways in the field of translation theory in application and enlightening research on translation. 
This corpus of guidelines, rules, norms and general knowledge about translation never ends and never runs dry. And that is the normal way of developing a well-established translation theory based on practice. A real development cannot be achieved by demolishing or downgrading this huge corpus of translation knowledge to be replaced with paradigms of uncertainty (e.g. the compatible relativist Skopos theory paradigm (see Pym, 2016) calling for sweeping norms and rules of translating as being prescriptive and unneeded in the translation theory.

(9) Oddly and vaguely enough, in the descriptive paradigm, the borders between translations and non-translations can be defined in terms of norms, which in turn express values from the wider system within which the translator is working. In this sense, the theory of norms positions translation somewhere between the relative certainty of equivalence and the relative indifference of Skopos theory (see Pym, 22016). This is another paradox by descriptivist theoreticians who resort again and again to norms which they shun and call to break for being prescriptive. Further, they do not state these norms leaving them vague of reference expressing "values from wider system" which is left undefined.

\section{Casting doubts on the meaning of translation}

Here is another theoretical problem that cuts to the heart of hollow theoricization, that is, casting doubts on the definition of the old-age meaning of the term "translation"! If so, exactly what criteria should we use for collecting a set of things called "translations"? Toury's solution to the problem has been to leave the redefinition of the well-known term of translation to the people they study. For him, a translation "...will be taken to be any target-language utterance which is presented or regarded as such [i.e. as a 'translation'], on whatever grounds" (Toury 1995a: 20. In Pym, 2016). In other words, we wait to see what each culture and each period has to say about what is or is not a translation. The solution is the operative concept of "assumed translations," which means to Toury (ibid.) that a translation is indeed a translation only for as long as someone assumes it to be one. 
A pseudotranslation, for example, might then be held to be a translation only for as long as the trick works, and it becomes a non-translation for those aware of the false pretence.

\section{Comments on casting doubts on the meaning of translation}

(1) It goes without saying that challenging the general meaning and definition of the term "translation' is an extremist contention put forward by Toury and company. They have gone too far in their resentful and daring challenge and understatement of translation theory and practice as a whole. It doesn't come to cast doubts on the term "translation" itself, which has an insidious aim of uprooting the basics and bases of this field of knowledge and highly proficient profession and practice. Toury has gone too far to leave the meaning of translation to the people, communities and cultures to be determined by each of them. In other words, he means to dismiss giving any definite meaning to translation, which is a preposterous call for liquidating the whole discipline altogether. Vagueness is looming again and again!

(2) A further strong objection to this illogical call is raised by contemporary translation theorists who say: "That solution remains fraught with logical difficulties. For example, if each language has different words for "translation", how do we know those words are translations of each other? In order to select the words, we would surely need our own concept of translation, if not some clear ideas about what good and bad translations are. The debate over that issue has been one of the most fundamental but recondite activities in Translation Studies (cf. among others Gutt 1991; Toury 1995b; Hermans 1997, 1999; Halverson 2004, 2007; Pym 1998a, 2007a. In Pym, 2016). For some, the problem is basically without solution, since if we use our normal terms to describe another culture's term "we naturally translate that other term according to our concept of translation, and into our concept of translation; and in domesticating it, we inevitably reduce it" (Hermans 1997: 19). 
The best we can do is to be honest and self-critical about our initial principles and criteria... (see ibid.). Put differently, it is unacceptable to question the meaning of translation which has been practiced for thousands of years now all over the world.

\section{Target-side priority}

Translation should be in terms of target language; the source text is a springboard for target language text. As we have noted, and in Pym's (2016) words, Toury insists that translations should be studied in terms of their target contexts rather than in relation to their sources (Toury 1995b: 136). He went to an extreme position and claimed that "Translations should be regarded as facts of target cultures" (39). He argues that the factors needed to describe the specificity of how translations work are within the target system. This is based on the assumption that translators "operate first and foremost in the interest of the culture into which they are translating" (1995a: 12). This position is not unlike that of purpose theory.

\section{Comments on Target-side priority}

(1) Toury and company, especially purpose theory proponents, seem to use the source text as a means to an end, i.e. to put it in the service of target culture the way that is appropriate to the target culture regardless of any respect to, or considerations of the source text. In other words, it is an outright call for exploitation of the source text in the translator's own interests taking it as a means to an end for whatever purpose that may meet his/her target culture. To me this is a stark invitation to rob and betray the source text and blast basic principles of translation: faithfulness, honesty and accuracy. In this case only do I agree that those translators are traitors indeed!

(2) Further, this principle of target-side priority has been contested by researchers working on literary translation in the 1990s generally preferred a "transfer" model, which explicitly traced movements between particular source and target cultures (see Pym, 2016). 
(3) Others have objected to the separation of the two cultures involved, arguing that translators tend to work in an "intercultural" space in the overlap of cultures (cf. Pym 1998a).

(4) More generally, as with the problem of defining translations, the binary opposition of source and target has been increasingly criticized from within the indeterminist paradigm, as we shall see later (see Pym, 2016).

(5) The skopos theory results in the dethroning of the source text and crowning the target text unjustifiably and unethically at the expense of the source text (Pym, 2016).

\section{The Fallacy of equivalence as a chimera}

Snell-Hornby calls 'linguistic equivalence' an illusion, a chimera. She says: "the term equivalence, apart from being imprecise and ill-defined ... presents an illusion of symmetry between languages which hardly exists beyond the level of vague approximations and which distorts the basic problems of translation" (1988: 22). Descriptivist theoreticians oppose the equivalence paradigm in that they aim to be non-prescriptive, their prime focus is on "shifts" rather than types of equivalence, and they do not undertake extensive analysis of the source culture. They tend to be like purpose-based Skopos approaches in that they emphasize the target-culture context and the function of translations within that context. To them, equivalence went out of fashion, and German-language Skopostheorie made it even more unfashionable by arguing that since "functional consistency" (the closest thing they had to equivalence) was no more than one of many possible requirements, translation usually requires transformations of a rather more radical kind. For those theorists, equivalence became quite a small thing, a special case. That is, to them, equivalence was a feature of all translations, in which case it could no longer be used to support any linguistics that would help people create it, nor could the concept directly serve the prescriptive training of translators (Pym, 2016). Further, in the historical context, the shift from prescription to description involved a clear challenge to the institutionalization of the equivalence paradigm. 
Rather than just tell people how to translate well (which is what and most equivalence-based linguistic analyses set out to do, along with Skopostheorie and hopefully most training institutions), descriptivist theories aim to identify how people actually do translate, no matter what the supposed quality. The equivalence paradigm mostly came from scholars who worked in linguistics or professional training; the descriptive paradigm was mostly peopled largely by researchers with a background in literary studies. (Pym, 2016). Translation to those theoreticians, then, is no longer a problem of merely finding verbal equivalents but also of interpreting a text encoded in one semiotic system with the help of another.

\section{Comments on the Fallacy of Equivalence as a chimera}

(1) In the light of understanding equivalence as a one-to-one equivalent conception, but, rather sense-to sense and sense-close-to-sense process, this notorious ant-equivalence thesis (or anti-thesis!) is similar to the notorious statement that 'translators are traitors' (Traduttori traditori). Contrary to Snell-Hornby's controversial statement and other antagonists of equivalence including prescriptivist theoreticians, equivalence is not a mirage, but, rather, an inescapable reality that is widespread in use by translation theorists and practitioners. When talking about translation, "the word 'equivalence' is sooner or later on everyone's lips", as Rojo states (2009: 31). In any translation practice, first and foremost, we look for an absolute equivalence, then to the closest, then to the next closest (whether individual words, or phrases/statements) for not everything can be translated exactly and perfectly into another language. So in the event, and if absolute equivalence is not possible or available, we go to the next best, the closest possible, or approximate equivalence. Hence 'proximity principle'.

(2) Indeed, this type of equivalence is what we really work on most of the time, and which we have to strive to achieve a close resemblance for, but we have to admit that many words and terms are translated approximately between English and Arabic more unconsciously than consciously, and more unwillingly than willingly. Religious and concept words like prayer, fast, 
pilgrimage, romanticism, naturalism, chancellor, president, etc. are all translated approximately, i.e., only a part of the meaning of each is translated. For example, Muslims' prayer, pilgrimage and fast are different from those of the Christians, but the general concept is the same. On the other hand, romanticism is translated into رومانسيةaas only a part of the meaning of the original. The two implications of lewdness and atheism are left out. By analogy, naturalism means infatuation in nature and worship of nature (i.e. atheism). Translated into Arabic, only the first meaning الطبيعية is intended, and the second meaning is dropped.

(3) Thus, equivalence is a reality in translation theory and practice. It is so easy to deceive ourselves and turn a blind eye to a glaring fact like equivalence in translation, and believe in heresies and fallacies that we have falsely convinced ourselves of. Equivalence is always hovering over the heads of the translators, any translators in the world for they are preoccupied with rendering the SL meaning into the TL as closely as possible by several means, tools and tactics. It is true that there are exceptions to that practice, but exceptions are exceptions. A genuine practical exercise is to say the following simple statement in Arabic now for the respected readers of this study who are not familiar with Arabic Language: (أحسنت صنعاً) and see what they are looking or asking for. We will find out that they are eager to know its equivalent meaning in English (which is "well done": a phrase as an equivalent for a whole sentence in Arabic). No other practice, mental or linguistic - is going on at the moment of hearing the Arabic statement. Isn't it the truth? Why complicate things and deny the existence of an inevitably existing activity? Equivalence is a fact, whether denied or not.

(4) Hornby (1988: 20-22) draws false evidence from the historical meaning of the word "equivalence" in both English and German to prove they are different, and the use of the word over six hundred years ago is originally not in the same sense as used today in translation, to come up with the conclusion that 'equivalence' is dubious in sense and, therefore, should be reconsidered and set aside in translation. Well, words may undergo several 
vicissitudes over history, which is quite normal and universal. Further, being different from the meaning of the German equivalent word is no reason to suspect its meaning. I mean to say that the meaning of the word equivalence is well-established as much in English as in many other live languages.

(5) There are many approaches to translation and translation methods in circulation these days. All of them are based mainly on the concept of 'Equivalence', however with variation. Equivalence is not taken here in the sense of one-to-one correspondence between the Source Language term and its Target Language counterpart. "Equivalence should be understood in a relative sense as the closest approximation possible to the meaning of the ST", as rightly pointed out by Rojo (ibid.: 22). Different types of equivalence have been in circulation in translation theory. Here is a list with the majority of them:

(1) Literal equivalence

(2) Free equivalence

(3) Linguistic equivalence

(4) Sociolinguistic equivalence

(5) Referential equivalence

(6) Cultural equivalence

(7) Pragmatic equivalence

(8) Non-pragmatic equivalence

(9) Stylistic equivalence

(10) Connotative equivalence

(11) Figurative / idiomatic equivalence

(12) Direct equivalence

(13) Indirect equivalence

(14) Formal equivalence

(15) Dynamic equivalence

(16) Communicative equivalence

(17) Functional equivalence

(18) Textual equivalence 
(19) Contextual equivalence (micro- \& macro-)

(20) Natural equivalence

(21) Artificial equivalence

(22) Idiolectal equivalence

(23) Creative equivalence (which is several types)

etc.

(6) Like descriptivist theoreticians, Snell-Hornby and protagonists of skopostheorie aim at deinstitutionalizing regularities and basics of translation including the term "translation" itself (see above) and the concept and paradigm of equivalence to replace it with baseless and opaque descriptivism, with the aim to uproot the term equivalence "which is the feature of all translations", to use their words. To me, quite the reverse is applicable in this case for a feature that is common to all types of translation is worth preserving all the time for it has proved to be true, rigorous and workable over time, which is a rarity among features and concepts. I do believe that their argument is in favour of equivalence as being a longestablished concept and practice in translation all over history, but they do not mean that.

(7) Suppose we drop equivalence from translation, what is the alternative then? It is quite misleading and disillusioning to devise alternatives such as descriptivist approaches and practices that are unrealistic, impractical and lack elaboration. Equivalence has been and will continue to be a hard fact for almost everybody in the field of translation that resists any attempts to dethrone it from the theory and practice of translation as well as from the minds of translators. If we may claim consensus for a term, concept or practice in translation theory, it must be "EQUIVALENCE".

\section{Conclusions and Results}

The following conclusions and results can be drawn from the foregoing discussion. Translation theory is far from perfect, yet it is there with basics, guidelines, regularities, norms, methods, methodologies, process of translating, ethics, 
tools and tactics that are flexible and changeable over time, and may vary from language to language, culture to culture, text to text, readership to readership and even from translator to translator. So it is not exactly prescriptive and stagnant in the strict sense of the words, as some theoreticians claim. This study is an appeal for translation theorists and practitioners to challenge some new trends in Translation Studies by some of its advocates to disrupt the whole body of translation theory and practice and destabilize them by casting doubts on all conceptions, activities and basics in the field, and replace them with baseless contentions and hypotheses. People in the field are strongly recommended not to rush and take up any new thesis in translation studies as a new development in translation theory. Even the term "Translation Studies", I suspect, is intended to replace "translation theory", implying that the latter is not mature enough yet to be called a theory. Indeed casting doubts on the basics of translation theory is aimed at calling its death on the hands of desriptivist theoreticians and open the door widely to desystematize and decanonnize translation theory with the pretext of developing it. Those theoreticians have contradicted themselves on several occasions and failed to put forward an alternative well-elaborated and well-established empirical frame of reference of translation theory for their trends, leaving that to the TL readership loosely and without elaboration. Theorization without concretization on the ground in practice is mere theoricisation, and description is an account of something but does not make up a theory. Besides that, a paradigm of practice-based, variable and flexible norms of translation and translating is indispensable to be a frame of reference, the sign of organization and authority of some kind to be consulted now and again by translators. Only a well-established theory of translations can be tolerated, be it perspective or otherwise. That is the natural way of all aspects of human life and good theories including translation theory.

Finally, I think we have to stop rushing for any new trend in translation theory desperately, unthinkingly and innocently for two main reasons: (1) it may be mere theoricisation; and (2) we are not necessarily required to believe anything new no matter who is or how authorised he/she might be. 
My last word to translation theoricists and theoreticians is: "stop baffling us in the name of new developments in translation studies or, rather, you mean translation theory!"

\section{References:}

Benson, M., Benson, E. and Ilson, R. (1986). The BBI Combinatory Dictionary of English: A Guide to Word Combinations, Clevedon: John Benjamins.

Boase-Beier, Jean (2006). Stylistic Approaches to Translation. St. Jerome Publishing. Manchester, UK \& Kinderhook, USA.

Crystal. D. (1987). The Cambridge Encyclopedia of Language, Cambridge University Press: Cambridge.

Duff, A. (1981), The Third Language, (Pergamon Press).

Frawley, W. (ed.) (1984). Translation: Literary, Linguistic and Psychological Perspectives. Associated University Press: London and Toronto.

Ghazala, H. (2007a). Dal El-Ilm Dictionary of Collocations: A Comprehensive English-Arabic Dictionary of Accuracy of Word Combination and Usage. Beirut: Dar El-Ilm Lil-Malayin.

Ghazala, H. (2015b). Translating Culture: A Textbook, Jedda, Saudi Arabia: Konooz Al-Marifa.

Ghazala, H. (2020). The First Arabic Encyclopedia of Translation الموسو عة العربية) (الأولى للترجمة. Jedda, Saudi Arabia: Konooz Al-Marifa.

Hamburger, H. (1994a). Foreign language immersion: science, practice, and a system. Journal of Artificial Intelligence in Education, 5:4:429-450.

(The) Holy Koran

Hönig, H. (1998). Positions, Power and Practice: Functionalist Approaches and Translation Quality Assessment. In Schäffner, C. (ed), Translation and Quality. Clevedon: Multilingual Matters, pp. 6-35.

Humboldt, W, V. (1992) From 'the Introduction to his Translation of Agamemnon' (Schulte,R. and Biguenet, J (1992). Theories of Translation: an Anthology of Essays From Dryden to Derrida. (Chicago and London: The University of Chicago Press), pp. 55-59. 
Hyde, G. (1993). The Whorf-Sapir hypothesis and the translation muddle', in Translation and Literature, 2: 4-16.

Jakobson, R. (1960). Closing statement: Linguistics and poetics, in Sebeok, T.A. (ed.). Style in Language. Cambridge: The MIT Press, 350-93.

Jakobson, R. (2000). On Linguistic Aspects of Translation, in Venuti, L. (ed.), (2000/ 2004). The Translation Studies Reader. London and New York: Routledge, 113-18.

Lefevere, A. (1992). Translation Rewriting \& the Manipulation of Literary Fame, (London and New York: Routledge).

Malmkjær, Kirsten (2005). Linguistics and the Language of Translation, Edinburgh: Edinburgh University Press.

Newmark, P. (1988/1995). A Textbook of Translation. London: Prentice Hall.

Nord, C. (1991). Text Analysis in Translation. Theory, Method, and Didactic Application of a Model for Translation-oriented Text Analysis. Amsterdam/Atlanta GA. Rondopi ( $2^{\text {nd }}$ edn. 2005).

Oxford (2002/2003). Oxford Collocations Dictionary for Students of English ( $4^{\text {th }}$ impression, 2003). OUP.

Pym, A. (1993). Text Analysis in Translation. Theory, Method, and Didactic Application of a Model for Translation-oriented Text Analysis (A Review), in TTR 6/2, 184-190.

Pym, A. (2010/2016) Exploring translation theory, London, Routledge

Robinson, D. (1997/2007). Becoming a Translator. London and New York: Routledge.

Rojo, A. (2009). Step by Step: A Course in Contrastive Linguistics and Translation. Peter Lang.

Sapir, E. (1956). Culture, Language and Personality. Berkeley, California: University of California Press).

Slobin, D.I. (1987). Thinking for speaking. Proceedings of the $13^{\text {th }}$ Annual Meeting of Berkeley Linguistics Society, 30: 435-444.

Snell-Hornby, M. (1988/1995). Translation Studies: An Integrated Approach, Amsterdam/Philadelphia: John Benjamins Publishing Company.

Toury, G. (1995). Descriptive Translation Studies and Beyond. Amsterdam and 
Academic Journal of Research and Scientific Publishing | Vol 3 | Issue 27

Publication Date: 5-7-2021 ISSN: 2706-6495

Philadelphia: John Benjamins.

Tyulenev, S. (2014). Translation and Society, by Sergey Tyulenev (2014):

Routledge: Taylor \& Francis Group. London and New York

Venuti, L. (ed.) (2000/2004). The Translation Studies Reader, London and New

York: Routledge.

Vermeer, H.J. (1996). A skopos theory of translation: some arguments for and against Heidelberg: TEXTconTEXT.

Whorf, B.L. (1956). Language, Thought and Reality (ed.) J.B. Carroll, Cambridge, Mass.: MIT Press).

Copyright @ 2021 Dr. Hasan Said Ghazala, AJRSP. This is an open-access article distributed under the terms of the Creative Commons Attribution License (CC BY NC).

Doi: doi.org/10.52132/Ajrsp.e.2021.273 